Témoigner Témoigner. Entre histoire et mémoire

Getuigen Revue pluridisciplinaire de la Fondation Auschwitz

Violences radicales en scène

\title{
The (im) possibility of theatrical representation
}

Dramatizing the Rwanda genocide

De (on)mogelijkheid van de theatrale voorstelling: bespiegelingen over de

dramatisering van de Rwandese genocide

\section{Klaas Tindemans}

\section{(2) OpenEdition}

Journals

Electronic version

URL: https://journals.openedition.org/temoigner/3377

DOI: 10.4000/temoigner.3377

ISSN: 2506-6390

Publisher:

Éditions du Centre d'études et de documentation Mémoire d'Auschwitz, Éditions Kimé

Printed version

Date of publication: 1 October 2015

Number of pages: $75-87$

ISSN: 2031-4183

Electronic reference

Klaas Tindemans, "The (im) possibility of theatrical representation", Témoigner. Entre histoire et mémoire [Online], 121 | 2015, Online since 01 October 2016, connection on 04 February 2022. URL: http://journals.openedition.org/temoigner/3377 ; DOI: https://doi.org/10.4000/temoigner.3377 


\section{The (im)possibility of theatrical representation} Dramatizing the Rwandan genocide

$\rightarrow$ Klaas Tindemans, VUB \& RITCS

School of Arts onathan Boyer was the first American racing cyclist to finish the Tour de France. Today he lives and works in Rwanda, where he coaches the national cycling team. His efforts to develop the best performing racing cycling team in Africa could be seen as a mild form of neocolonialism, with Rwanda being an ex-colony of Belgium, the motherland of racing cycling. Rwanda is the land of the thousand hills, roads going up and down; the ideal training ground for cyclists. When Boyer's team runs through these hills, the landscape is not just a beautiful backdrop for competitive sportsmen on expensive Eddy Merckx-bikes. These cyclists run through a countryside overwhelmed with memories. After a ride, they talk about the ruined houses they cycled past. They talk about the massacres taking place in these houses, now more than twenty years ago, during their childhood, they talk about slaughtered families and miraculous survival. Other boys don't say anything. Their families were also implicated in the genocide of 1994, but on the other side. Jonathan Boyer's team is composed of racing cyclists from both Hutu and Tutsi backgrounds (van Gelder 2012). Since the actual regime in Rwanda does not accept any official use of this divide, only the stories and the histories are left, cruel as they are. As everywhere in Rwanda, families of survivors and victims live together with families of perpetrators. The official policy of the regime of President Paul Kagame stimulates - some would say forces - victims and perpetrators of the genocide to share the villages. This policy is in place since the return of the first Hutu refugees from Zaire/Congo in 1996. If the blurring of the difference between perpetrators and victims is anathema in reflections and studies about the judeocide, the material reality of the aftermath of the Rwandan genocide blurs the distinction quickly.

This contribution focuses on the representation of the Rwandan genocide in four theatrical productions, which relate to the domain of memory and trauma and offer very different answers to questions concerning the relationship between the individual and the collective victim, or between survivors and perpetrators. Though using various and diverging scenic and dramaturgical strategies, the tension between document and testimony, on the one hand, and fiction and theatralization, on the other, is always sensible as a problem of representation. It is this tension which determines, to a large extent, the position of the spectator who needs to assess, intellectually and affectively, the ethical significance of the representation. 


\section{DOSSIER}

The (im)possibility of theatrical representation (continuation)
Reflections on representation and representability of the cruelest months in the history of Rwanda - from 6 April until the 19 July 1994 - should thus take into account a crucially different societal reconstruction of Germany of 1945, where most of the survivors of the genocide had moved to other countries, transatlantic or transmediterranean. In Rwanda the imagined and constructed collective identities justifying both the invasion of Kagame's army in 1990 and the genocide by the "Hutu Power" militia in 1994, these identities have simply ceased to exist. Yet the success of the scarification of this putative ethnic divide is highly questionable.

It is significant that theatrical representations of this theme, produced in the northern hemisphere, consider their impact on present-day Rwanda and its population as an important criterion of artistic success. Representation matters, for the Rwandan but also for the European audience, since they share a (post) colonial past. Three productions are made in Europe, with a European or a mixed cast and by European directors; the fourth is made with Rwandans in Rwanda, but with a northern text and by a northern theatre director. The 'European' productions (Rwanda 1994 by Groupov/Jacques Delcuvellerie, Ruanda Revisited by Hans-Werner Kroesinger and Hate Radio by IIPM/Milo Rau) deal, unavoidably, with the colonial past of Germany, Belgium and France in the region of the Great Lakes. They confront the audience, directly or indirectly, with historical responsibilities. Even what looks like a 'dry' re-enactment (Hate Radio) of a local episode of the genocide points cannot avoid touching these issues. The fourth production, The Monument by Isôko/Jennifer H. Capraru is of a completely different kind: it universalizes trauma, instead of historicizing the outbreak of collective violence. Before describing the details of those productions, some preliminary remarks about collective traumas and their representation should be made.

\section{REPRESENTATION, ETHICS AND TRAUMA}

While Claude Lanzmann considered the Holocaust as a material event, as "unrepresentable", and qualified any representational operation therefore as a falsification of the archives, Didi-Huberman believes that representations of documents and testimonies might help an audience to define and to refine the relationship between "absolute evil" and historical massacres and genocides. It is clear that no representation of ineffable cruelty, be it by "fabulation" or by a framed narration of "bare facts" can render the proportions of large-scale massacres, let alone genocides - no matter what medium, performing arts or visual arts, is used. But maybe this disproportionality with the historical events counts, paradoxically, for its representational (plus-) value. The awareness of this condition can turn the representation into a political statement: imagination - dramaturgy, sense of space, sense of matter - should take up this task (Didi-Huberman 2003, 119-121; 220-221).

By definition, we deal here with representations of trauma, and it could be relevant to refer to the link between the suffering of violence, especially in its traumatic representation, and Freuds "death drive". The key traumatic moment is not the 
experience of reliving the event, but the enigma of survival: the trauma is defined by the impossibility to remember one's survival and every attempt to claim one's own survival shatters. This incomprehensibility is the heart of Freud's notion of the death drive (Caruth 1996, 64-65). In Moses and Monotheism Freud develops this idea of "survival as a trauma" as a meta-psychological theme: trauma-after-violence has historical impact beyond any pathological condition. On this collective level, the history of "chosenness" - as in the case of the people of Israel - is equivalent to the history of survival. Collective identities always take the form of an unending confrontation with the returning violence of the past, Cathy Caruth concludes. The non-experience of a group being unharmed after an incident and not knowing the reasons of its survival, shapes the trauma as a repetition of an unknown scene (Ibid., 69-71).

Caruth's thesis is open to critique in its negligence, rather important in Freud's meta-psychology, of the unanswered question whether the "primal scene" of violence is a historical truth or a collective phantasm, a myth. And when he deals with historical trauma, Freud clearly distinguishes, in the representation of the violent facts, between written history and oral transmission. This distinction inserts the issue in the field of distorted representations - distorted by the pleasure principle. And the idea of (collective) trauma as a literal repetition which is subject to periods of latency remains controversial. Caruth claims that "history, like trauma, is never simply one's own, that history is precisely the way we are implicated in each other's traumas" (Ibid., 23-24).Critics object that knowledge of neurosis and trauma cannot put literary and factual repetitions on the same level, thus blurring not only the distinction between facts and fiction, but also between victims and perpetrators. The killer's compulsive repetition of his deeds, conceived as a part of mutual implications in a traumatic representation, is put on the same level of veracity as the victim's, thus resulting in a suspicious kind of historical complicity (Leys 2000, 292-297). Especially in artistic representation - sometimes labeled as "writing trauma", whereas historiography writes about trauma, this blurring carries risks. One could make an ethical distinction in the artistic representation of collective violence with respect to their various degree of emotional investment or to the truth claims made in these representations, as Dominick LaCapra advocates, but the incomprehensibility (in individual terms) and the indecidability (in collective terms) remains (LaCapra 2001, 181-219). In a certain sense, both documentary and metaphorical representations of mass violence in general and of Rwanda in particular cover the field from generalized existential emptiness - the tragic feel - to personal legal accountability.

The historical mourning of the Holocaust, it could be said, took at least one generation to start. The societies of both victims and perpetrators withheld the "working through" of their memories, they kept silent about historical facts and perspectives. These societies kept at distance, constructed their own identities, Verfassungspatriottismus in the Federal Republic of Germany, state Zionism in Israel. It is probably the capture of Eichmann which triggered, both in Israel and in Western Europe, a process of historicization, of putting the Holocaust in a complex 
The (im)possibility of theatrical representation (continuation) context of societal responsibilities, ideological strategies and social pathologies. In the case of the Rwanda genocide of 1994, conditions were very different. The RPF-government that ended the genocide in July 1994 banned the idea of separated collective identities within Rwanda altogether and, in a certain sense, tried to derive its political legitimacy from the genocide itself. This different form of mourning has an undeniable influence on the traumas as they are represented, artistically or not.

\section{RWANDA 94: THE ANTI-TRAGEDY}

Jacques Delcuvellerie, the initiator of Rwanda 94, calls his project "une tentative de réparation symbolique envers les morts, à l'usage des vivants" - "an attempt of symbolic reparation for the dead, to be used by the living" (Groupov 2002, 7). He distances himself explicitly from the opinion of "wise men"(Lanzmann?) according to whom genocidal horror - and the Holocaust in particular - is "unknowable" so that attempts to analyze its causes cannot render full account of it. Rwanda 94 is conceived as an interrogation, by the survivors and by the dead, of those virtually and really responsible for the cruelest genocidal destruction since the Holocaust. This relationship is clear, in its intention: the Rwandese survivors talk to the European - especially Belgian - spectators, observers of a historical genocide, while hardly being aware to which degree their politicians were involved in it. This direct confrontation is further politicized by a Belgian "analyst", who refers to the scars of the colonial past.

On its formalist surface, Rwanda 94 looks like a Greek tragedy, in the tradition of Aeschylus' Persians. The Chorus of the Dead confronts "Bee Bee Bee", a journalist, with testimonies about the genocide, whereas this protagonist, much like Aeschylus' character of Xerxes, is forced to assume fatal responsibility for the catastrophe. Their spoken chants, a mixture of lamentations and accusations, are interrupted by a reading, by Jacques Delcuvellerie himself, on the colonialist roots of the genocide: the construction of the ethnical division between Hutu and Tutsi by German and Belgian authorities, the disputable role of the Catholic Church and of the Belgian and French governments after decolonization. We also see, as re-enactments or as fragments from televised news archives, all kinds of opinions about the events. But the impression of fatality is betraying: the play and, even more strongly, the performance, choose sides. It does even more: it calls names. As Olivier Neveux says:

These proper names testify in fact on the possibility to force the situation, to create an excess to it, not reducible, without the possibility to appropriate it to its course and its immanence. [...] The proper names, respectful for the singularity of everyone, acquire the value of political enunciations. [...] They impose themselves, as a truth, as a "supplement" to the ordinariness of existence. They tear fatality to pieces. By this, they "sign" the events, they claim - without coercion - trustworthiness. (Neveux 2007, 255) 


\section{EXTREEM GEWELD OP/IN SCÈNE}

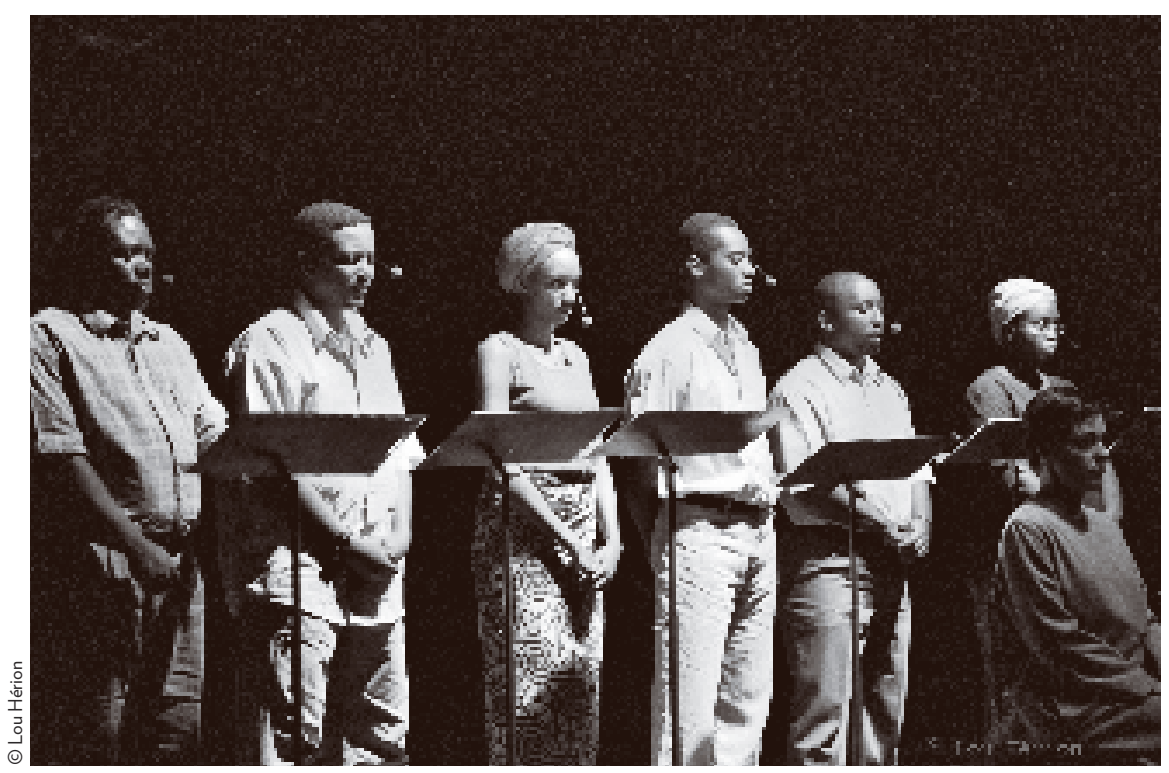

The "enchantment" with proper names is framed by a litany of pertinent questions. No open ends or loose threads of existential doubt, but clear interrogation: "Will they talk about the shocking testimony of Janvier Afrika on the role of the French soldiers in the training of the interahamwe militia?" or "Will they talk about the help from father Johan Pristill with the translation of Mein Kampf of Adolf Hitler, on the account of the Hutu-extremist Martin Bucyana?" Rhetorical questions indeed, but they invite to unambiguous inquiry. When the Chorus of the Dead continues almost endlessly its accusatory testimonies, the journalist collapses and bursts into tears. At the final series of performances, in 2004 in Kigali, the capital of Rwanda, a member of the audience takes her handkerchief and gives it to Joëlle Ledent, the actress who plays Bee Bee Bee. Although the line between victims, perpetrators and their direct and indirect accomplices is clearly drawn, the theatrical event itself blurs the distinction between the "good guys" and the "bad". On an emotional level, the "melodramatic" narrative of a journalist (Bee Bee Bee) implicitly re-visiting the Holocaust, makes a "classical" identification possible, notwithstanding the brechtian dramaturgy of the documentary material. This blurring - comparable to the reversal of emotions in some tragédies sanglantes ${ }^{1}$ of the late $16^{\text {th }}$ century in France- is the more forceful, since the performance has opened with an extremely realistic narration of the atrocities by an actual survivor. It should be clear for everyone what happened and it should be as clear that human beings who continue to live among us - with proper names - are responsible for it. What follows should be an inquiry into the responsibilities, not into the nature of humanity and a fortiori not into fatality. Rwanda 94 is a journey through an endless landscape of political violence. The
- Rwanda 94,

Groupov, 2002.

(1) The tragédie sanglante is the French counterpart of the English "revenge tragedy". The genre competed with real executions, with the theatricality of the gallows. Dramaturgically, it is characterized by a preference for violent exotic situations - also, due to the prohibition, in the Édit de Nantes (1598), to represent the domestic religious wars - and by extreme reversals of emotional roles (Biet 2006; 2014; Enders 1999). 
The (im)possibility of theatrical representation (continuation)
European observer - the journalist and the audience, identifying with her - travel along scenes where manifestations of (neo-)colonial power and African rituals are intertwined, thus reflecting a broad picture of a certain "world order" - with the Rwandese genocide as an all too rational consequence: the assimilation of racialized (non-)values in the Catholic church, the presence of the "international community", the ghost of colonialism as represented in a portrait - an effigy - of French President François Mitterrand. This parade of accomplices ends with a requiem: the cantata of Bisesero. The whole journey, using different theatrical forms such as puppetry and masque, is accompanied by the strong ambient music of Garrett List, as a menacing voice without words. And the repetition of the trauma - including the political lament - is not pathology, it becomes, by its sheer insistence, a moral requisite in a process of mourning. The perpetrators - or their representatives: the European audience - are participating in this ceremony, and the continuous political contextualization doesn't allow these observers any escape, let alone any form of catharsis.

\section{RUANDA REVISITED: THE LESSON OF THE GENERAL}

Hans-Werner Kroesinger created with Ruanda Revisited (2009) a performance of a completely different kind, although he concurs with Jacques Delcuvellerie in his refusal of a fatalistic reading of the so-called tragic events. Kroesinger focuses even more on the "white side" of the events, in the first place by casting five Caucasian German actors - and a European audience. Kroesinger, specialized in "documentary theatre", always frames non-fiction texts - documents re-arranged along non-conventional but doubtlessly "dramatic" lines - in a slightly provocative setting. In Ruanda Revisited five actors in conventional "bureaucratic" suits enter the stage and introduce the audience in the history of Ruanda, completely with PowerPoint-presentations, geographical maps and short filmed excerpts. They focus on the role of UNAMIR - the United Nation Mission in Ruanda - and their commander, Canadian general Roméo Dallaire. The basic text of this performance is a long interview in the television show Frontline of PBS, after a number of suicide attempts and other "pathetic" events in his life after the failure of his efforts. When the Dallaire-character is introduced, the actors guide the audience to another performing space, after a walk through a tunnel, a dark gallery with small pictures of the genocide on the walls: you have to come close to the photo to see the horror, or you can simply avoid the confrontation. The audience arrives in a kind of (uncomfortable) military tent, and has to sit on folding chairs. The interview text of Dallaire, together with other testimonies about the political aftermath of the Rwandese debacle, continues to serve as the dramaturgical backdrop, but the interventions of the actors become more and more direct, until they tell their atrocious stories, face to face, to individual members of the audience. Finally, the audience is redirected to the "normal" stage. In a final scene, without commentary, they look at their own empty seats, the actors are the only survivors in this theatrical void. The dialectics of Kroesinger's performance, its tension between the biased reconstruction of the events through the existential 

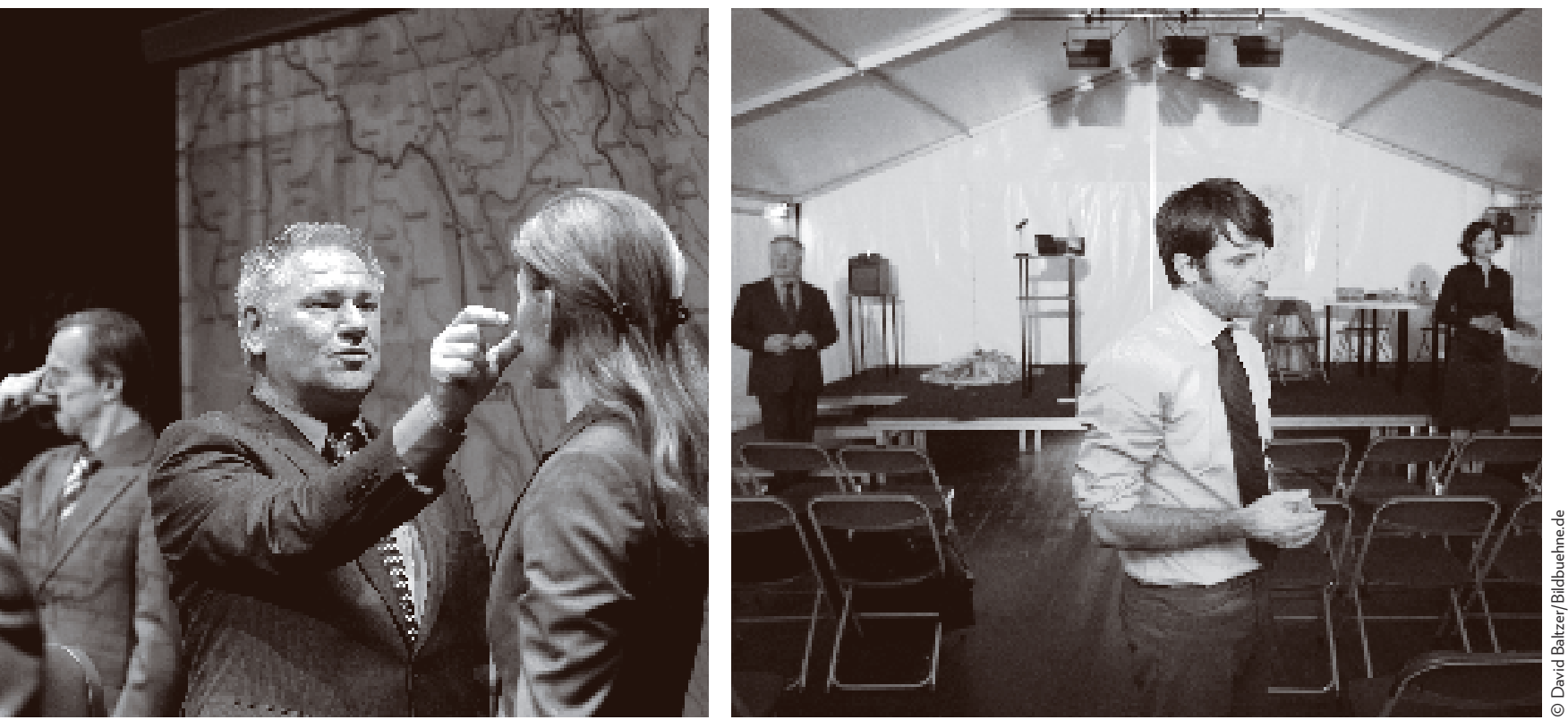

- Ruanda Revisited, Hans-

crisis of general Dallaire and the investment of this narrative in spaces provokWerner Kroesinger, 2009. ing the spectator's gaze, is difficult to compare with the predominantly brechtean dramaturgy of Groupov's Rwanda 94. Groupov starts with “naked” testimony: the spectator sees the slaughter of the family before his or her eyes and is deeply touched by both the bare facts and the frankness and bravery of the witness, realizing she must have told this story over and over again. The dialectics are staged between this sheer emotionality and forms of rational analysis: Delcuvellerie's own dry reading and the precise statements and questions by a Chorus of the Dead. Empathy or identification with Bee Bee Bee might be a mechanism in Rwanda 94, but she continues to be the outsider, her personal drama is theatrically "instrumentalized". In contrast to Greek tragedy, where a chorus can philosophize about man and progress in front of an obvious crisis ${ }^{2}$ - see Sophocles' Antigone - this chorus shows the procedures of an imaginary, idealized international penal court. With the character of general Dallaire Kroesinger introduces a middleman, a liminal figure, whose status is enhanced by the documentary "truth claim" (Tindemans 2013). Dallaire acquires the position of the survivor: his story makes the dry political facts digestible, but at the same the audience is aware of the "futility" of a depression - even including his suicide attempts - compared with the extent of the genocide. Thanks to the emotional impact, both in the testimony and in the professional chaos represented by the journalist, judgment is possible, even in the legal sense. But one thing never happens, not in Kroesinger's incriminatory performance or in Groupov's "pathetic" analysis: the final judgment of the accused. ${ }^{3}$

(2) The chorus in ancient tragedy embodies the precarious position of the "emancipated" Athenian citizen in the polis of the $5^{\text {th }}$ century B.C.: as a character, it intervenes with (futile, even petty-bourgeois) pragmatism in the mythos where (half)gods are entangled in, as an autonomous scenic body, they use dithyrambic verses in their quest for a metaphysical ground under their "secularized" condition. See Meier 1988 and Vernant \& VidalNaquet 1972.

(3) One interesting exception to the "gratuity" of documentary theatre could be the use of theatrical tools to trigger confessions in the gacaca courts - the popular tribunals dealing with "minor" génocidaires. See Breed 2008. 


\section{DOSSIER}

The (im)possibility of theatrical representation (continuation)

_Hate Radio, IIPM, 2011.

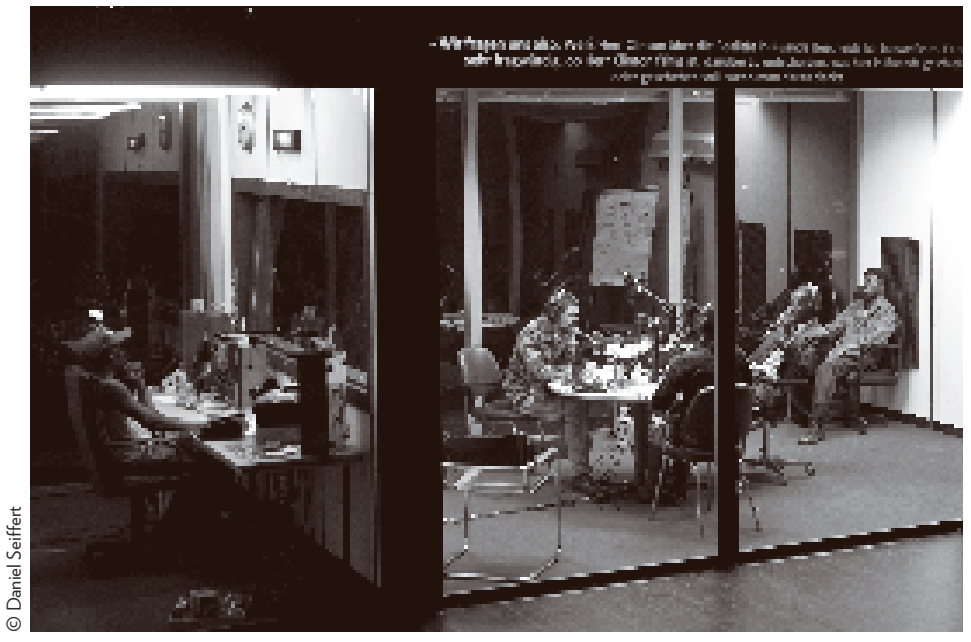

HATE RADIO: THE SITUATION

Milo Rau, Jens Dietrich and their organization "International Institute for Political Murder" (IIPM), who conceived Hate Radio, call their project a "situation", not a re-enacted document. The difference is significant, since it implies a radical decontextualization of an event. This event is a broadcast of Radio-Télévision Libre des Mille Collines (RTLM). RTLM was the radio station, founded in 1993, that made its name by mixing "fun radio" with racist anti-Tutsi messages. IIPM reconstructs more than one hour of radio show, supposedly the last broadcast of the station from Kigali, in the beginning of July 1994, although the content of the performance is in fact a combination of earlier shows. But the general atmosphere is clear: three moderators and a DJ, a silent soldier, African music, Nirvana, Joe Dassin and extremely biased messages. Even the world news is filtered through the ideology of Hutu Power, although the selection of results from the soccer World Cup (Germany against Belgium, both former colonizers) looks more like a dramaturgical joke. The performance is dramatically pointless, the real time of the radio show is filled. But whereas this central part cannot be seen from a distanced point of view - apart from the subtitles, translating the French and the Kinyarwanda of the moderators in English and German - the framing of this "real time" situation is quite invasive. Four witnesses, three of them actually the performers in the reconstructed RTLM-radio studio, tell their story on videotape. Personal stories, the kind of testimonies Groupov used in Rwanda 94. The recording however changes their character: the repetition, characteristic of a live performance, doesn't reside in the testimony, but in the re-enactment of the role in the studio. The actors-survivors re-enact and repeat, night after night, the position of the perpetrators. Even when, from an audience point of view, the illusionism is structurally different - direct testimonial truth versus indirect re-enacted truth - the switch is selfevident. The testimonials even reinforce the suspension of disbelief during the broadcast show. A simple technical device adds to the uneasy intimacy of the setting: each spectator wears headphones, the performing space as such remains silent. The isolated audio turns the event, rather paradoxically, in a community of abhorrence - an incontrovertible experience. Hate Radio is a performance without any trace of fiction or metaphor, without any obvious dramaturgical interference, thus reducing the horror as mediated in Rwanda 94 - by the presence of journalist Bee Bee Bee - and in Ruanda Revisited - by 


\section{EXTREEM GEWELD OP/IN SCÈNE}

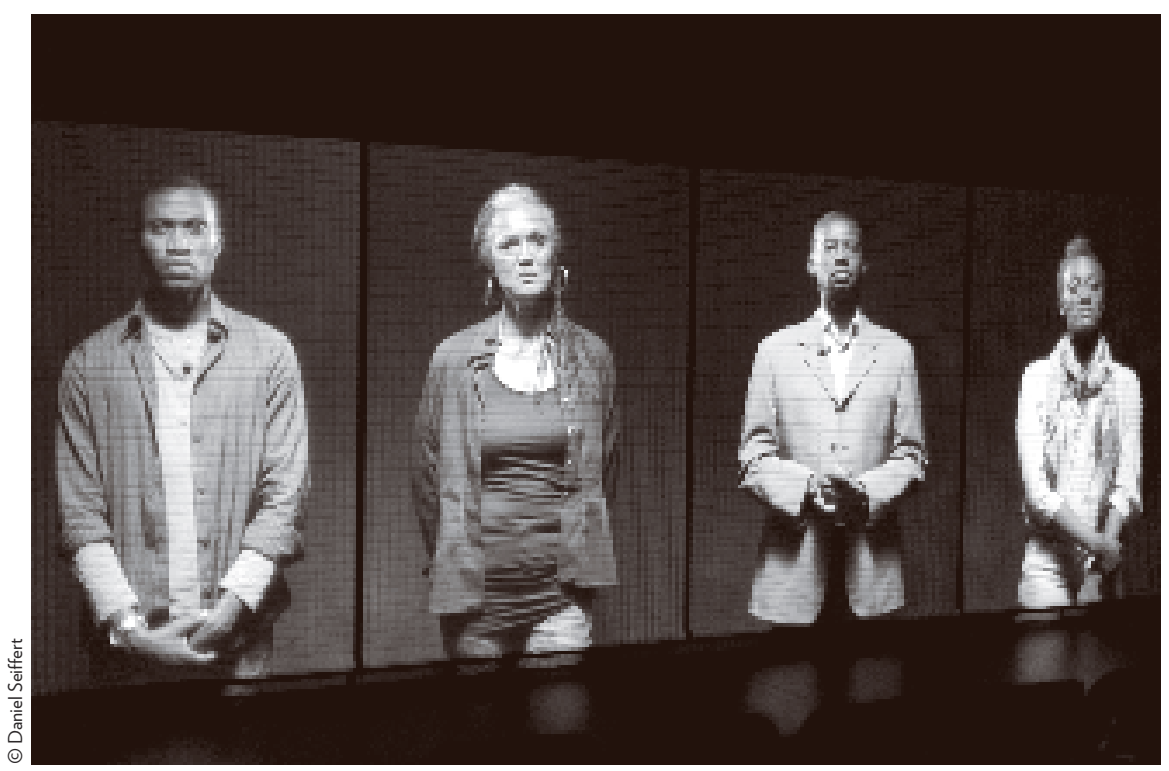

_Hate Radio, IIPM, 2011.

the white "lecturers" and its demonstrative structure - to its bare facticity. This re-enacted situation competes, at a certain level, with the vicarious reality of televised news. Both staged realities - the testimony and the "situation" - have a certain "a-historicity" in common, they cut the event or the situation loose from the history of (de)colonization, although in a meaningfully different way. Hate Radio sketches, in a couple of slides, very shortly the antecedents of the 1994 genocide - RPF invasion, plane crash on 6 April, omnipresence of the semi-official RTLM - but the performative condition is mainly shaped by the juxtaposition of testimony and re-enactment. Even when televised news is as sketchy as Hate Radio in its framing of antecedents, the confrontation of horrific images with a testimony longer than a "sound bite" rarely takes place. It is precisely this use of time - the time of story-telling, the time of one hour broadcast radio - that makes the impact of this theatrical representation substantially different. In this sense, you can hardly speak of a competition between mass media and theatre, since each uses its own codes of theatricality - especially with regard to time and space. In Rwanda 94 the document is "historicized" and "theatricalized" by its anti-tragic dramaturgy and its mixture of actual and indirect testimonies, all embedded in a narrative structure. Ruanda Revisited breaks up the realism of the document by the use of different spaces: a college room, a dark tunnel lightened by horrifying pictures, a white tent of some undefined NGO. And Hate Radio stages real time in all its insufferability. In this way, the experience comes quite close to the exhibition of the rare pictures of the gas chambers, denounced by Claude Lanzmann, defended by Georges Didi-Huberman (Didi-Huberman 2003, 11-28). The radio studio is a weapon of mass destruction, or at least a metaphor of it. 
The (im)possibility of theatrical representation (continuation)

\section{THE MONUMENT: A HEALING PROCESS}

Canadian director Jennifer H. Capraru founded the Isôko theatre in Rwanda with the goal to make an artistic contribution to the healing process in the country, and the production of The Monument (2010) is their first project. This explicitness marks an important difference from the (semi-)documentary theatre analyzed above. The Monument isn't a documentary theatre production at all. It is an adaptation of a Canadian play by Colleen Wagner, treating a traumatic and sometimes sadomasochistic encounter between a perpetrator and the mother of a victim, probably in the 1990s in former Yugoslavia, translated in Kinyarwanda and put in the Rwandan context, with only slight alterations of the basic text. Contrary to a production as Hate Radio, which explicitly focuses on the particularity of a factual situation, The Monument universalizes the genocide, even when the dramatic "incident" of this ambiguous encounter is only a fictional footnote in an orgy of mass violence. In Rwanda, where the production toured all over the country, memorials of the genocide often try to repeat, in their architecture and design, the prosaic reality of the massacres: skulls and skeletons in desecrated places, objective witnesses of the fundamental disrespect for humanity, even after the killing. The Monument does the opposite, it turns a traumatic confrontation into a ritual of its own kind, into a symbol of the necessity of memory, of "working through" - as LaCapra defines it: no pathological "acting out" - the experience. The confrontation turns into a process of mourning, individually and, by the nature of a representation in front of a live audience, collectively. The staging uses signs and codes to strengthen this symbolic aspect of the play: little candles burning, displayed in a circle around the actual performing space, suggest a connection with Jewish rituals, the presence of dead victims in silent characters refers to the acceptance of ghosts in Rwandese culture. The audience sits around this circular "stage", whereas the ghosts appear from the liminal corridor between spectators and performers. An idea of (passive) participation in the ritual is installed, and - according to Capraru's own observations - the Rwandese audience also interprets the performance in this way, although not uncritically. In its atmosphere, the performance walks the thin line between mourning and melancholia, especially as the "monument" of the title takes shape in the "transformed" body of the perpetrator. Even when the story accepts the reality of the killings now worked through in this encounter, it is hard to be sure whether the dead girls are an objective loss or a mythicized absence. In this sense, the production thematizes, although in an abstract form, the political over-determination of the genocide: it makes the "holes" in the Rwandese society, both on a local as on a national level, visible, but without the possibility to sublimate it in political capital, as the Kagame regime tries to do the past twenty years. Objectifying the loss in acts and objects of memorialization is tricky. The Monument treats exactly this remarkable aspect of the societal mourning process in contemporary Rwanda: the official reconciliation, the ideological redefinition of "forgiveness", as expressed in the amazement of observers such as Philip Gourevitch (1998, 312-212, quoting Rwandan president 


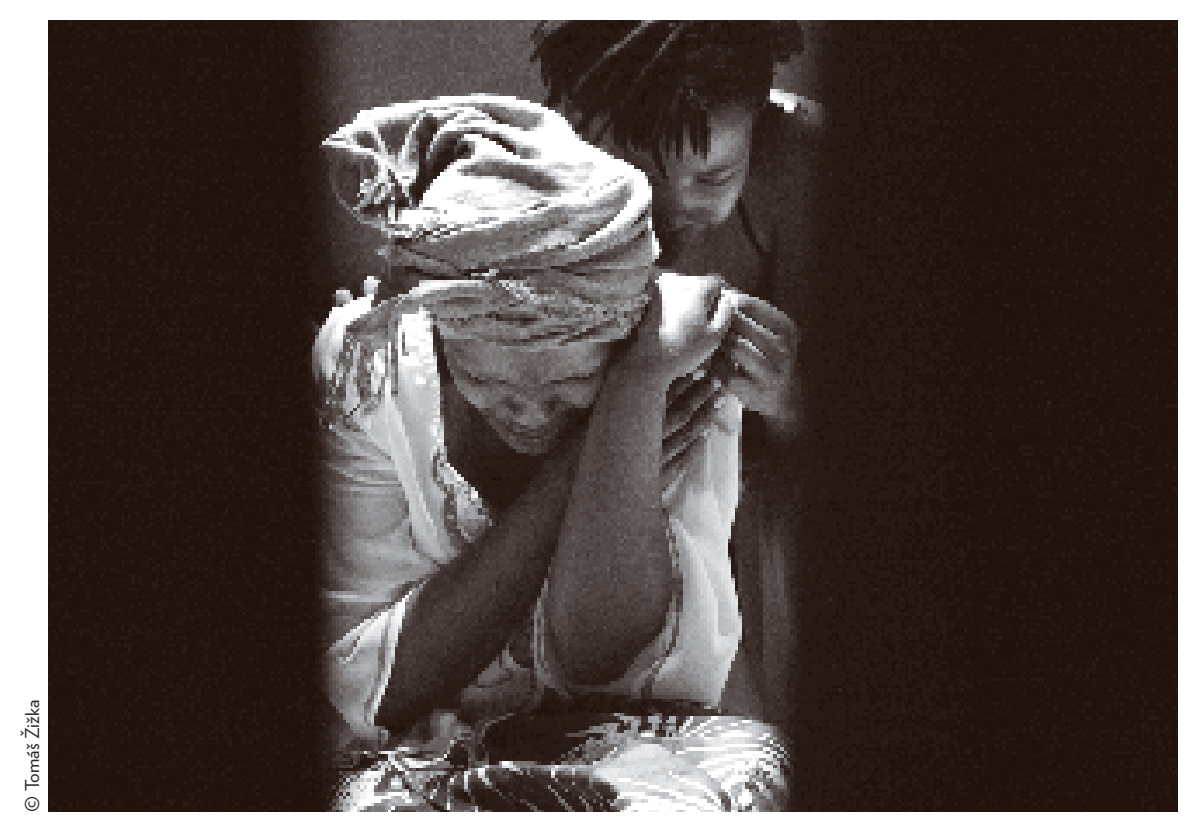

Paul Kagame). Director Capraru notes that the audience, especially in rural venues, criticizes the ritual form of the performance, compared to their direct, undecorated experience of the massacres and their (political) memorialization. Ritual, as a collective experience which transforms the structure of this mourning society and, has no place in the national "working through" of the genocide, unless you consider the official recuperation by the memory culture of the regime as a ritual as well: but that comes closer to brainwashing. In spite of this reservation, the Rwandese audience connects to the existential fundamentals of The Monument, such as the predatory nature of the mother-daughter relationship. And this is the explicit objective of the work of Jennifer H. Capraru and the Isôko; they call it "applied theatre", in order to help rebuild a shattered civil society (Capraru 2009).

\section{CONCLUSION}

Dramatic or dramatized representation of the Rwandan genocide is of course no privilege of the theatre. Docudramas such as Hotel Rwanda and Shooting Dogs represent the courageous but sometimes futile attempts to save at least those who sought refuge in isolated sanctuaries: a hotel, a school. This type of representation is generally situated on the level of compassion, its dramaturgy takes the mechanisms of identification for granted. They try to catch the horror within an individualized framework, but they rarely deal with the societal trauma of Rwanda and the Rwandese population that survived. A lot of journalism follows the same pattern, starting
- The Monument,

Coleen Wagner/Jennifer

H. Capraru,, 2010. Jaqueline

Umubeyi (Mejra) and

Solange Umuhire (Ana). 
The (im)possibility of theatrical representation (continuation)

(4) In the specific sense of "impossible witnessing" as suggested byShoshana Felman, i.e. the impossibility to witness from the inside, because the inside equals death: she reaches this conclusion in her analysis of Claude Lanzmann's Shoah (Felman 1992, 231). with Philip Gourevitch's award-winning We Wish to Inform You That Tomorrow We Will Be Killed with Our Families. The subtitle is typical: Stories from Rwanda. A provocative political statement such as Complices de l'inavouable. La France au Rwanda, by Patrick de Saint-Exupéry (2009)- he points at the alleged complicity of the French political class with Hutu Power, before, during and after the genocide - stages his story, quite pathetically as it happens. The author tells the story of the implication of President François Mitterrand as a fictive revisit of crucial locations in Rwanda and France, accompanied by former Foreign Minister Dominique de Villepin. He confronts him with what he describes as the trauma of French decolonization, Rwanda being the repetition of the loss of Indochina and Algeria. Gourevitch wrote an independent Hollywood script; de Saint-Exupéry imitates the tragédie classique, Racine's Brittanicus perhaps.

The possible strength of the theatrical productions I reflected upon is their common attempt to deal with trauma, mourning and healing as a collective process. Even the deliberately "situational" production Hate Radio participates in a discourse of historical qualification of a horrific event which, like the Holocaust, made witnessing impossible. ${ }^{4}$ These dramatizations, all dealing with the question of the position of the audience in a very conscious way, do not consider the individual story as a reliable repetition of the events. The individual story can trigger the analysis, but cannot bring it to an end, not even a provisional one. In these productions, direct, recorded or vicarious testimonies are the starting point for a more or less violent theatrical process of "naming names" (Rwanda 94), of revisiting historical and actual accountabilities (Ruanda Revisited), of exposing the "structure of desire" in the perpetrators (Hate Radio) or the ambiguities of healing (The Monument). In a completely different way as the early Modern tragedy did, they juxtapose themselves next to the framed accounts of mass media - mainstream journalism and docudrama alike. They challenge their veracity, their historical parameters, their almost doctrinaire balances between individual and collective pathos. In The Monument director Jennifer H. Capraru explains the objectives of her work in contemporary Rwandese society, whereas the other productions, primarily aimed at European audiences, do not speculate openly about their intended effects. But nevertheless, they are part of the general need of representation, not only of individual stories, but of societal processes, a need to deal with the impending cultural traumas our fragmented societies are suffering from. A genocide as an argument ex absurdo.

\section{WORKS CITED}

- Agamben, Giorgio, Remnants of Auschwitz. The Witness and the Archive, New York: Zone Books, 2002.

- Biet, Christian (ed.), Théâtre de la cruauté et récits sanglants en France (XVle-XVIle siècle), Paris: Robert Laffont, 2006.

- -, 'Les leçons de l'Édit de Nantes ou les théâtres de la catastrophe (XVle-XVIle siècles vs $X X^{e}-X X l^{e}$ siècles)', Témoigner entre histoire et mémoire 117, 2014, 82-92, http://temoigner.revues.org/752 (accessed 21 September 2015). 


\section{EXTREEM GEWELD OP/IN SCÈNE}

- Breed, Ananda, 'Performing the Nation. Theatre in Post-Genocide Rwanda', The Drama Review, 2008, 32-49.

- Capraru, Jennifer H., 'Memory, Memorial and The Monument: Contested Memories in Rwanda, a Field Report', alt.theatre - cultural diversity and the stage 6 (3), 2009, 15-22.

- Caruth, Cathy, Unclaimed Experience. Trauma, Narrative and History, Baltimore \& London: Johns Hopkins University Press, 1996.

- de Saint-Exupéry, Patrick, Complices de l'Inavouable. La France au Rwanda, Paris: Édition des Arènes, 2009.

- Didi-Huberman, Georges, Images malgré tout, Paris: Les Éditions de Minuit, 2003.

- Enders, Jody, The Medieval Theater of Cruelty. Rhetoric, Memory, Violence, Ithaca: Cornell University Press, 1999.

- Felman, Shoshana \& Dori Laub, Testimony. Crises of Witnessing in Literature, Psychoanalysis, and History, New York \& London: Routledge, 1992.

- Gourevitch, Philip, We wish to inform you that tomorrow we will be killed with our families. Stories from Rwanda, New York: Farrar, Straus and Giroux, 1998.

- Groupov, Rwanda 94, Paris: Éditions Théâtrales, 2002.

- LaCapra, Dominick, Writing History, Writing Trauma, Baltimore \& London: Johns Hopkins University Press, 2001.

- Leys, Ruth, Trauma. A Genealogy, Chicago \& London: University of Chicago Press, 2000.

- Meier, Christian, Die politische Kunst der griechischen Tragödie, München: C.H. Beck, 1988.

- Neveux, Olivier, “Les noms qui sauvent". Une opposition militante à l'idéologie du tragique (à partir de Rwanda 1994 du Groupov)' in Christian Biet, Paul Vanden Berghe \& Karel Vanhaesebrouck (eds), (Edipe contemporain? Tragédie, tragique, politique, Paris: L’Entretemps, 2007, 241-256.

- Tindemans, Klaas, 'Regard et réalité. Le spectateur du théâtre documentaire', théâtre/public 208, 2013, 34-37.

- van Gelder, Elles, 'Hutu trekt sprint aan voor Tutsi', DS Weekblad, 18 February 2012, 50-55.

- Vernant, Jean-Pierre \& Pierre Vidal-Naquet, Mythe et tragédie en Grèce ancienne. Tome I, Paris: François Maspero, 1972. 